\title{
THE CHROMOSOME COMPLEMENT OF BLASTOCYSTS FROM RABBITS INJECTED WITH VARIOUS DOSES OF HCG BEFORE OVULATION
}

\author{
EVELYN L. SHAVER \\ Department of Anatomy, University of Western Ontario, London, Ontario, Canada
}

(Received 5th May 1970)

In a previous study, the effect of delayed fertilization of ova on the chromosome complement of 6-day blastocysts was investigated (Shaver \& Carr, 1969). Human chorionic gonadotrophin (HGG) causes ovulation to occur in rabbits approximately $10 \mathrm{hr}$ after injection. When mating was delayed at least 6 $\mathrm{hr}, 13 \%$ of the blastocysts were found to be triploid. Triploidy was not found in the control series, although blastocysts from animals mated immediately after HCG injection had a 7\% incidence of other types of chromosomal anomalies. Rabbits receiving no exogenous gonadotrophin gave rise to only $2 \%$ of blastocysts with abnormal chromosomes. This difference led to an experiment in which various doses of HCG were injected before mating in order to determine whether a relationship existed between the dose level and the chromosomal abnormalities found in 6-day blastocysts.

Adult rabbits of mixed breeds purchased from a local supplier were used. Eleven rabbits were injected intravenously with doses of HCG ('APL' Ayerst Laboratories) varying between 75 and 300 i.u. immediately before mating with a fertile male. Details of the method employed for recovery and preparation of the blastocysts for chromosomal analysis have been published (Shaver \& Carr, 1967). Ghromosome counts were made from thirty metaphase plates from each blastocyst, where possible. Karyotypes were prepared according to the classification of the chromosomes of the rabbit by Nichols, Levan, Hansen-Melander \& Melander (1965).

The results are summarized in Table 1. One hundred and ten corpora lutea were counted in the ovaries and eighty-four blastocysts were recovered on Day 6 from the eleven rabbits. Ovaries from rabbits receiving 300 i.u. HCG showed evidence of gross overstimulation with many large, bright red unruptured follicles present. Seventy-five out of eighty-four of the blastocysts $(90 \%)$ were examined chromosomally. The remaining nine blastocysts were of small size with few mitoses, and could not be studied. The diploid number of chromosomes for the domestic rabbit is 44. Two chromosomal abnormalities were found. One of these occurred in an animal which received 75 i.u. HGG. This blastocyst was found to be a $43 / 44$ mosaic with an XY sex chromosome complement in the cells with 44 chromosomes. One of the small acrocentric chromosomes was missing in the cells with 43 chromosomes and it was impossible to 
determine whether it was an autosome or the Y-chromosome. The second chromosomal anomaly occurred among blastocysts recovered from an animal which had been injected with 300 i.u. HCG. The blastocyst was found to have 44 chromosomes with a deletion of the short arms of one of the medium length submetacentric chromosomes. The sex chromosome complement of this blastocyst was also XY. The remaining seventy-three blastocysts were found to have a normal chromosome number and karyotype, forty-two blastocysts having an XY-, and thirty-one an XX-sex chromosome complement (Table 1).

\section{TABLE 1}

NUMBER OF CORPORA LUTEA, BLASTOCYSTS AND CHROMOSOME ANALYSIS OF BLASTOCYSTS FROM RABBITS RECEIVING VARIOUS DOSES OF HCG IMMEDIATEL.Y BEFORE MATING

\begin{tabular}{|c|c|c|c|c|c|c|c|}
\hline \multirow{2}{*}{$\begin{array}{l}\text { Dose } \\
\text { HCG } \\
\text { (i.u.) }\end{array}$} & \multirow{2}{*}{$\begin{array}{c}\text { No. of } \\
\text { animals }\end{array}$} & \multirow{2}{*}{$\begin{array}{c}\text { No. of } \\
\text { corpora } \\
\text { lutea }\end{array}$} & \multicolumn{2}{|c|}{$\begin{array}{c}\text { No. of } \\
\text { blastocysts }\end{array}$} & \multicolumn{3}{|c|}{ Chromosome analysis } \\
\hline & & & Recovered & Examined & $x r$ & $X X$ & Abnormalities \\
\hline $\begin{array}{r}75 \\
100 \\
200 \\
300\end{array}$ & $\begin{array}{l}3 \\
3 \\
3 \\
2\end{array}$ & $\begin{array}{l}33 \\
26 \\
30 \\
21\end{array}$ & $\begin{array}{l}28 \\
18 \\
24 \\
14\end{array}$ & $\begin{array}{l}23 \\
17 \\
21 \\
14\end{array}$ & $\begin{array}{r}12 \\
10 \\
12 \\
8\end{array}$ & $\begin{array}{r}10 \\
7 \\
9 \\
5\end{array}$ & $\begin{array}{l}\text { A } 43 / 44 \text { mosaic } \\
\text { A deletion of the } \\
\text { short arm of a sub- } \\
\text { metacentric chromo- } \\
\text { some }\end{array}$ \\
\hline Total & 11 & 110 & 84 & 75 & 42 & 31 & 2 \\
\hline
\end{tabular}

To determine whether increased levels of gonadotrophin administered during the time when the first polar spindle of the ovum is forming would adversely affect the chromosome complement, three rabbits were injected with 75 i.u. HGG $4 \mathrm{hr}$ after mating. According to Pincus \& Enzmann (1935), this is the time when the nuclear membrane has disappeared and the tetrads have formed in the rabbit ovum. No chromosomal abnormalities were found among twenty-one blastocysts examined from these rabbits.

Excess HCG has been reported to affect capacitation of spermatozoa in rabbits (Soupart, 1967; Wettemann \& Hafs, 1970) and to lead to a higher incidence of abnormalities in the zona pellucida of the ovum of the baboon (Katzberg \& Hendrickx, 1966). On the other hand, Bedford (1970) could find no evidence that administration of excess HCG at the time of mating inhibited the capacitation of spermatozoa. The present study of 6-day blastocysts recovered from rabbits treated with increased amounts of HCG during the time of ovum maturation gave no indication that excess chorionic gonadotrophin adversely affects the chromosome constitution of developing ova.

This study was supported by a grant from the Medical Research Council of Ganada.

\section{REFERENGES}

BEDford, J. M. (1970) The influence of oestrogen and progesterone on sperm capacitation in the reproductive tract of the female rabbit. F. Endocr. 46, 191. 
KATZBerg, A. A. \& Hendrickx, A. G. (1966) Gonadotropin-induced anomalies of the zona pellucida of the baboon ovum. Science, N.Y. 151, 1225.

Nichols, W. W., Levan, A., Hansen-Melander, E. \& Melander, Y. (1965) The idiogram of the rabbit. Hereditas, 53, 63.

Pincus, G. \& Enzmann, E. V. (1935) The comparative behavior of mammalian eggs in vivo and in vitro. I. The activation of ovarian eggs. $\mathcal{F}$. exp. Med. 62, 665 .

Shaver, E. L. \& GARR, D. H. (1967) Chromosome abnormalities in rabbit blastocysts following delayed fertilization. 7. Reprod. Fert. 14, 415.

Shaver, E. L. \& GARR, D. H. (1969) The chromosome complement of rabbit blastocysts in relation to the time of mating and ovulation. Can. F. Genet. Cytol. 11, 287.

Soupart, P. (1967) Studies on the hormonal control of rabbit sperm capacitation. F. Reprod. Fert., Suppl. 2, 49.

WetTEMANN, R. P. \& HAFs, H. D. (1970) Sperm capacitation after injection of LH or HCG in rabbits. Proc. Soc. exp. Biol. Med. 133, 1002. 